Boston University School of Law

Scholarly Commons at Boston University School of Law

Faculty Scholarship

$1-2005$

\title{
Arbitration: Governance Benefits and Enforcement Costs
}

Keith N. Hylton

Boston University School of Law

Follow this and additional works at: https://scholarship.law.bu.edu/faculty_scholarship

Part of the Law Commons

\section{Recommended Citation}

Keith N. Hylton, Arbitration: Governance Benefits and Enforcement Costs, in 80 Notre Dame Law Review 489 (2005).

Available at: https://scholarship.law.bu.edu/faculty_scholarship/667

This Article is brought to you for free and open access by Scholarly Commons at Boston University School of Law. It has been accepted for inclusion in Faculty Scholarship by an authorized administrator of Scholarly Commons at Boston University School of Law. For more information, please contact lawlessa@bu.edu.

BOSTON 


\section{HEINONLINE}

DATE DOWNLOADED: Fri Sep 23 19:03:57 2022

SOURCE: Content Downloaded from HeinOnline

Citations:

Bluebook 21st ed.

Keith N. Hylton, Arbitration: Governance Benefits and Enforcement Costs, 80 NOTRE DAME L. REV. 489 (2005).

ALWD 7th ed.

Keith N. Hylton, Arbitration: Governance Benefits and Enforcement Costs, 80 Notre Dame L. Rev. 489 (2005).

APA 7th ed.

Hylton, K. N. (2005). Arbitration: governance benefits and enforcement costs. Notre Dame Law Review, 80(2), 489-500.

Chicago 17th ed.

Keith N. Hylton, "Arbitration: Governance Benefits and Enforcement Costs," Notre Dame Law Review 80, no. 2 (January 2005): 489-500

McGill Guide 9th ed.

Keith N. Hylton, "Arbitration: Governance Benefits and Enforcement Costs" (2005) 80:2 Notre Dame L Rev 489.

AGLC 4th ed.

Keith N. Hylton, 'Arbitration: Governance Benefits and Enforcement Costs' (2005)

80(2) Notre Dame Law Review 489

MLA 9th ed.

Hylton, Keith N. "Arbitration: Governance Benefits and Enforcement Costs." Notre Dame Law Review, vol. 80, no. 2, January 2005, pp. 489-500. HeinOnline.

OSCOLA 4th ed.

Keith N. Hylton, 'Arbitration: Governance Benefits and Enforcement Costs' (2005) 80

Notre Dame L Rev 489

Provided by:

Fineman \& Pappas Law Libraries

-- Your use of this HeinOnline PDF indicates your acceptance of HeinOnline's Terms and Conditions of the license agreement available at https://heinonline.org/HOL/License

-- The search text of this PDF is generated from uncorrected OCR text.

-- To obtain permission to use this article beyond the scope of your license, please use: Copyright Information 


\title{
ARTICLES
}

\section{ARBITRATION: GOVERNANCE BENEFITS AND ENFORCEMENT COSTS}

\author{
Keith N. Hylton*
}

\section{INTRODUCTION}

It is difficult to talk about arbitration from a theoretical perspective without saying things that are equally applicable to law in general. Much of what I will say in these remarks sketch out a theory of law and law enforcement, or norms and norm enforcement. Arbitration can be viewed as just one special and important application.

We can think of law as creating a web of rules within which social intercourse is supposed to take place. Alternatively, you can think of law as providing a frame, like the frame of a building. Either way, it is a structure, a spine, a basic set of parameters within which people are free to arrange their affairs.

Now, once you have spun this web of rules, how do you get people to stay inside it? There will be individuals who will want to stick their fingers outside of the web, and may want to do so on a regular basis, perhaps because they get some private gain by refusing to stay within the structure that everyone else is abiding by. The usual way of getting people to stay within the web of rules is through enforcement. That typically involves setting a penalty that falls on the person who violates a norm or legal rule. We can think of this as a hammer that someone holds as he stands on the other side of the web of rules. When he sees a finger poke through the web, he hits it hard with his hammer, creating sufficient pain to deter the offender and likeminded others from poking their fingers through the web.

* Professor of Law and Paul J. Liacos Scholar, Boston University, knhylton@bu.edu. This paper is based on my remarks at the January 2004 AALS Annual Meeting session on "Competing or Complimentary Rule Systems? Adjudication, Arbitration, and the Procedural World of the Future." 
Enforcement is not the only way to guarantee norm or law compliance. We can also rely on repeat dealing, reputation, and reciprocity. Someone who breaches contracts regularly will find that there are few others willing to trade with him. If his potential associates are rational, they will take even the slightest hint that he is unreliable as a strong signal to keep their distance. In the repeat-contracting setting, the norm-violator's conduct will bring its own punishment. However, outside of the contract setting, we find other settings in which repeat dealing may not be observed. A thief who burgles houses in the middle of the night does not have to worry about repeat dealing because success in his conduct depends on avoiding detection by others.

The law itself plays a role in controlling conduct, separate and apart from the force or penalty applied by any enforcement authority. While introducing the web metaphor, I described enforcement as if it were carried out by someone standing outside of the web wielding a hammer. The law itself sets the rules, or the boundaries of the web. Society might choose to change the boundaries to make it more or less difficult to avoid being found in violation of the law in some cases. For example, if we know that the hammer-wielder will catch only fifty percent of the norm-violators, we may want to change the norm (or law) so that it is difficult for a violator to avoid being found in violation. We might reduce the number of defenses, or the amount of evidence necessary to prove a violation of the law. For example, if we think law enforcement authorities are unlikely to catch most people engaged in price-fixing, we might structure the law so that there are few defenses available to anyone charged with price-fixing. This is, in fact, what we see.

It should be clear from this description how arbitration should be described. The courts, and the common law, provide the normal, or default, set of rules and enforcement conditions. Arbitration provides an alternative set of rules and enforcement procedures. For parties who can choose to submit their disputes to arbitration, they have a choice between two legal regimes: the court regime and the arbitration regime. Arbitration, in effect, provides the parties with the opportunity to set up a different set of rules-that is, to structure a web that is shaped differently from that spun by the courts. Also, arbitration provides them the opportunity to appoint a different hammerwielder, one who hits harder or perhaps more softly, or more or less frequently, than we see under the court regime. 
In the remainder of these remarks, I will sketch a framework for choosing between alternative legal regimes. ${ }^{1}$ I will start by sketching the basic theory and then move on to see whether the theory is consistent with empirical evidence. The theory emphasizes two key aspects to the choice between legal regimes: governance benefits and enforcement costs.

\section{Governance Benefits and Enforcement Costs}

Any set of rules governing interaction among private parties is likely to provide a benefit for which the parties are willing to pay. For example, the simplest type of benefit may be coordinating their conduct, like the rules of order (i.e., who moves when) in a game. More complicated and controversial rules will govern the amount of risk that one can impose on others. The parties will be willing to pay an amount that reflects the costs saved by having rules. A rule against breaching contracts, if complied with perfectly, provides an ex ante benefit equal to the expected net cost (i.e., loss to victim less gain to breaching party) of a breached contract. ${ }^{2}$ I will refer to the ex ante benefits provided by rules as governance benefits.

In order to secure these benefits, the parties will have to bear some costs. One cost is the cost of writing rules. When parties rely on the common law as the source of rules, the cost of writing rules is bundled into the fixed costs of having courts. Those costs are not borne entirely by the parties to a particular dispute because they are part of the general government budget, and shared by all individuals, whether litigants or not. In addition to the cost of writing rules, the most significant cost borne by potential litigants is the enforcement cost. Since we are talking about private litigation, enforcement costs are usually the costs of litigating to enforce the rules governing private interaction.

It follows that any set of rules governing private conduct can be described as having governance benefits and enforcement costs. The courts generate rules that have clear governance benefits, to the extent they describe and proscribe socially undesirable conduct, and enforcement costs, since the rules must be enforced by the very individuals who benefit from them.

In settings where parties are repeat dealers, or involved in longterm contracts, they are in a position to compare the governance ben-

1 The argument is based largely on Keith N. Hylton, Agreements to Waive or to Arbitrate Legal Claims: An Economic Analysis, 8 Sup. CT. Econ. Rev. 209 (2000).

2 For a richer analysis of governance benefits in the contractual context, see OLIver E. Williamson, The Economic Institutions of Capitalism 68-84 (1985). 
efits and enforcement costs of the rules governing their conduct. They can decide whether a certain rule is too expensive, because the governance benefit associated with that rule is less than its enforcement cost. If they decide that a particular rule is too expensive, they may agree among themselves to waive the rule. If parties are rational and well-informed, they will waive a legal rule whenever the governance benefit from the rule is less than the enforcement cost.

"Now wait a minute," you might say, "why would someone who is protected by a legal rule waive it, merely because the expected total cost of enforcement is greater than the total governance benefit?" Even if the total governance benefit is less than the total enforcement cost, it may still be the case that for that individual who is protected by the rule, the governance benefit he enjoys is greater than the enforcement cost he would bear. Assuming a setting of repeat dealers, there will be an opportunity, if transaction costs are low, for that individual to be compensated ex ante for waiving the rule. ${ }^{3}$ Since total welfare would be enhanced by waiving enforcement of the rule, there is a set of transactions that would leave all parties better off under an agreement that waives the rule. This is just an application of the Coase theorem. ${ }^{4}$

Why might the governance benefits of a legal rule fall short of its enforcement costs? In some cases, the harm that results from a violation is too small to justify the expense of going to court. The claims could be aggregated and brought on a class-wide basis. Alternatively, these matters could be treated as issues that will be dealt with through repeat dealing, reputation, or reciprocal conduct (tit-for-tat). In other cases, the likelihood of a real violation of the norm may be so small that the expected governance benefits of the rule are clearly less than the expected enforcement costs generated by frivolous claims.

Even if the governance benefit of a legal rule is greater than its enforcement cost, there may still be an incentive to waive it if the differential between governance benefits and enforcement costs is not

3 Compensation could take the form of an implicit understanding that if you ignore the slight harms I inflict on you, I will ignore the slight harms you inflict on me. Alternatively, one of the parties might agree to some concession to the other party, with an implicit understanding that the other party will not litigate over some issue in the future. On the adoption of norms (sometimes involving the waiver of strict rights) that deviate from the explicit law, see generally RoBert Ellickson, Order Without Law: How Neighbors Settle Disputes 123-30 (1991).

4 A rough statement of the Coase theorem is as follows: if transaction costs are low, parties will find side payments that will lead them to adopt the most efficient allocation of resources. See R. H. Coase, The Problem of Social Cost, 3 J.L. \& Econ. 1 (1960). 
sufficiently large. Again, suppose that parties are involved in repeat dealings. Any party that breaches the rule would be punished by a refusal by the other party to deal with him. Since punishment by titfor-tat refusals to deal or through group ostracism may be an effective means of enforcing group norms, the parties may decide to waive the legal rule. ${ }^{5}$ The legal rule, in this scenario, provides insubstantial incremental governance benefits, while at the same time introducing a substantial enforcement cost.

The same considerations that go into the decision to waive a legal right go into the decision to arbitrate. Arbitration provides an alternative forum in which parties can structure rules and enforcement methods so that the difference between governance benefits and enforcement costs is larger than in the default regime represented by ordinary courts. Why might the difference between governance benefits and enforcement costs be larger under arbitration than in the court system? There are several possible reasons.

First, one might find that the governance benefits associated with a given rule can be enhanced by moving into the arbitration regime. Suppose, for example, that a court is likely to make mistakes when deciding whether a group norm was violated. If the court is likely to make mistakes, the governance benefits associated with that particular rule could be enhanced by having it enforced in a regime in which adjudication is more accurate. ${ }^{6}$ Under a more accurate regime, people who were innocent of violating the norm would have less reason to fear that they would be punished by mistake, and people who had violated the norm would have less reason to expect that they would escape punishment. To return to the web analogy that I began with, the arbitration regime may be one in which the norm-enforcer swings his hammer more accurately than under the court regime.

Second, even if the governance benefits from a particular rule are the same within the court regime and within arbitration, a group might find that the enforcement cost is much lower within arbitration. For example, with a more accurate set of decisionmakers, the parties might find that the evidentiary burdens of proving their arguments in court are lower under the arbitration regime. Thus, even if there are no governance benefits associated with enhanced accuracy, there may

5 For such a waiver to occur, it is not necessary for the parties to get together and sign a formal waiver contract. They may decide to conduct their affairs, as Ellickson found in Shasta County, California, without resort to lawsuits. See Ellickson, supra note 3 , at 130 .

6 Hylton, supra note 1, at 223-26; see Steven Shavell, Alternative Dispute Resolution: An Economic Analysis, 24 J. Legal. STud. 6 (1995) (using an economic analysis to determine benefits and choices of parties regarding dispute resolution options). 
be substantial enforcement cost savings. In addition, the arbitration regime may be able to develop a special efficiency or productivity in considering disputes of a given nature. This will reduce the cost of enforcement for claims falling within its ambit.

Third, one should note there is a close connection between enforcement costs and governance benefits. An increase in enforcement costs can reduce governance benefits. If the cost of enforcing is too high relative to the private benefit a litigant gets from bringing suit, he will drop his claim. But that means rule violators whose victims fall within this group are effectively shielded from the law. They will continue to act in a socially undesirable manner. It follows that an arbitration regime may enhance governance benefits simply by introducing a cheaper method of claim enforcement.

Congestion provides an important reason why arbitration agreements may involve cheaper enforcement costs than the court regime. Congestion in ordinary courts makes it less likely that any court will have the time or resources to match the level of accuracy in adjudication that repeat dealers are likely to desire. Congestion also introduces delay, which increases the cost of enforcement. Given these costs, it is quite plausible that sophisticated parties who are repeat dealers will prefer to set up their own arbitration regime rather than submit all of their disputes to the courts. Of course, this preference may not be put into effect because it is costly to set up an arbitration regime. And to do so involves foregoing some of the governance benefits already provided by courts.

One well-known argument against the contractualist approach taken here points to the importance of external effects. According to the argument, arbitration may be socially undesirable because it reduces the stock of publicly accessible legal rules and stunts the development of law. ${ }^{7}$ It follows from this argument that individuals, or groups, may be too quick from a social standpoint to commit their disputes to arbitration. The reason is that they fail to take into account the benefits externalized to others when they litigate in the courts.

The externality critique of arbitration raises potentially important issues, but there are reasons to doubt the importance of the issues too. If the argument is understood as opposing any agreements that divert

7 For the most general source for such arguments, see Owen M. Fiss, Against Settlement, 93 YALE L.J. 1073 (1984). For the argument applied to arbitration, see Edward M. Morgan, Contract Theory and the Sources of Rights: An Approach to the Arbitrability Question, 60 S. CAL. L. Rev. 1059, 1081-82 (1987) (arguing that the Supreme Court's decision in Mitsubishi Motors Corp. v. Soler Chrysler-Plymouth, Inc., 473 U.S. 614 (1985), has permitted party autonomy to govern state-imposed objectives). 
disputes away from a final judgment in court, including settlement agreements, then it must be regarded as an untenable position. Settlements tend to occur when the law is relatively clear and neither party has a desire to seek to change it. Banning settlements will therefore do little to enhance the stock of publicly accessible legal rules. ${ }^{8}$ If the argument is understood as opposing only arbitration agreements, then its concerns could be met by requiring that the law developed within arbitration be made publicly accessible, rather than banning arbitration altogether. In addition, parties opt for arbitration in some cases to secure enhanced governance benefits. In such cases, the gains to the parties will be substantial while the external costs imposed on others are likely to be trivial and remote. ${ }^{9}$

Much of the foregoing argument depends on the ability of parties to make intelligent choices. The most obvious case in which this does not hold is that of mandatory arbitration. I am not using the term "mandatory arbitration" to refer to arbitration contracts in the employment setting, as many writers do. I refer to state-mandated regimes that require litigating parties to go into arbitration before entering the courts. ${ }^{10}$ There is no guarantee in the case of state-mandated arbitration that arbitration will go into effect when and only when the difference between governance benefits and enforcement costs is greater within arbitration than in the courts. Indeed, mandatory arbitration may have the perverse effect of driving up the overall cost of litigation, ${ }^{11}$ as litigants realize that in order to pursue their claims, they may have to go through arbitration and then into

8 Hylton, supra note 1 , at 244.

$9 \quad I d$. at $245-47$. Of course, in the final analysis, the externality critique of arbitration raises issues that should be resolved by examining empirical evidence. The arguments in the text merely show that the externality critique is not persuasive on theoretical grounds. What if the externality critique cannot be evaluated empirically? Then the critique should be viewed as a purely speculative argument that awaits some empirical verification.

10 Many states have enacted statutes requiring arbitration for certain types of civil disputes before a trial. States requiring arbitration in at least some circumstances include Alaska, Arizona, California, Connecticut, Delaware, Florida, Hawaii, Michigan, Minnesota, Nevada, North Carolina, New York, Oregon, Pennsylvania, Rhode Island, Texas, and Washington. See Lucy Katz, Compulsory Alternative Dispute Resolution and Voluntarism: Two-Headed Monster or Two-Sides of the Coin?, 1993 J. DisP. Resol. 1, 8 n.37. For an empirical analysis of one type of state-mandated arbitration, see Donald Wittman, Lay Juries, Professional Arbitrators, and the Arbitrator Selection Hypothesis, 5 Ам. L. \& ECON. Rev. 61 (2003).

11 See Lisa Bernstein, Understanding the Limits of Court Connected ADR: A Critique of Federal Court-Annexed Arbitration Programs, 141 U. PA. L. Rev. 2169, 2211-12 (1993) (analyzing the impact of mandatory arbitration). 
the courts. This realization may lead potential claimants to drop their claims, which in effect provides an immunity shield to rule violators.

The other case in which real choice might not be observed is that of the so-called adhesion contract. I refer to contracts in which one of the parties is offered a take-it-or-leave-it standard form and may be effectively uninformed about the terms of the deal. He signs the form because he feels in some sense coerced to sign. If one of the parties signs an agreement to arbitrate without being aware of the terms of the deal, he may find that he has entered a regime in which the governance benefits, for him, disappear entirely.

However, the adhesion contract theory must be viewed as a theory or hypothesis and not much more. People sign take-it-or-leave-it contracts all the time without being fully aware of all of the terms of the deal. We often rely on what we see of the experiences of others. We see that a neighbor bought a high-tech refrigerator and it works quite well. We decide on the basis of that neighbor's experience to buy one ourselves. Or we rely on the reports provided by consumers to a neutral source. The mere fact that someone signs a contract without being aware of all of its terms does not tell us whether the provisions of the contract were, or whether any particular provision of the contract was, a bad or good deal.

The mere fact that an arbitration agreement appears as a take-itor-leave-it provision of a contract does not tell whether or not the offeree signed the contract based on a reasonably informed choice over his alternatives. Nor does it tell us whether or not the offeree gained an ex ante benefit from signing the contract. If he gained a benefit from signing the contract, and had reason to expect that he would, he should be held to his agreement in most cases.

Whether arbitration agreements specified in adhesion contracts are socially undesirable is an empirical question. ${ }^{12}$ Given this, the argument against arbitration contracts framed in adhesion contracts should be taken as a hypothesis to be tested. The question to test is as follows: if we confine ourselves to contracts of adhesion, is the difference between governance benefits and enforcement costs lower for arbitration than for the courts? Until someone answers this question, the argument for banning arbitration agreements set out in take-it-orleave-it contracts is based on speculation.

12 For a detailed examination of the issues, see Stephen J. Ware, Paying the Price of Process: Judicial Regulation of Consumer Arbitration Agreements, 2001 J. Disp. Resol. 89. 


\section{Empirical. Evidence}

Now let's consider the empirical evidence. As far as I am aware, few studies have attempted to find evidence of governance benefits from arbitration. Most empirical studies in this area examine the results of arbitration-e.g., damage awards and plaintiff win rates. ${ }^{13}$ Perhaps the most careful of the recent studies is one by Theodore Eisenberg and Elizabeth Hill. ${ }^{14}$

Eisenberg and Hill present empirical evidence on the results of non-civil rights employment disputes heard by courts and by arbitrators. They find that for high-pay employees (more than $\$ 65,000$ per year) the outcomes from arbitration and litigation are the same. ${ }^{15}$ The win rates and mean damage awards are roughly equal in their samples of arbitrated and litigated cases. ${ }^{16}$ However, they also find a substantial plaintiff win rate (forty percent) for claims brought by lowpay employees in arbitration. ${ }^{17}$ In addition, in the sample used by Eisenberg and Hill, the total number of claims taken into arbitration by low-pay employees (eighty-eight) exceeds the total number of claims taken into arbitration by high-pay employees (seventy-seven). ${ }^{18}$

In interpreting Eisenberg and Hill's results, one should keep in mind that very few low-pay employees bring employment disputes into court. As they note in their paper, most attorneys say that the damage award must be at least $\$ 60,000$ in order to cover the costs of litigation. ${ }^{19}$ Most low-pay employees are unable to find an attorney willing to prosecute their claims.

Keeping this fact in mind, the Eisenberg and Hill results suggest that arbitration may provide substantial governance benefits in the workplace. If high-pay employees are receiving roughly the same treatment in arbitration as they get in court, and low-pay employees are able to pursue claims that would otherwise never gain the atten-

13 See, e.g., Lisa B. Bingham, Employment Arbitration: The Repeat Player Effect, 1 EMPLOYEE RTS. \& POL'y J. 189, 205-17 (1997) (analyzing how knowledge of multiple arbitration affects employees); William M. Howard, Arbitrating Claims of Employment Discrimination: What Really Does Happen? What Really Should Happen?, DisP. Resol. J., Oct.-Dec. 1995, at 40, 44.

14 Theodore Eisenberg \& Elizabeth T. Hill, Employment Arbitration and Litigation: An Empirical Comparison (Mar. 5, 2003) (unpublished draft), available at http:/ /ssrn.com/abstract $=389780$. For a closely related paper, see Elizabeth Hill, Due Process at Low Cost: An Empirical Study of Employment Arbitration Under the Auspices of the American Arbitration Association, 18 OHIO ST. J. ON Disp. Resol. 777 (2003).

15 Eisenberg \& Hill, supra note 14, at 14-19.

16 Id.

17 Id.

$18 I d$. at 14.

19 Id. at 10. 
tion of a competent lawyer, then the total number of claims against employers must be larger under arbitration. This suggests that the governance benefits are larger under arbitration, at least in the area of non-civil rights employment claims. Moreover, the issues that are of special concern to low-pay employees are more likely to be addressed in arbitration.

The only paper to look directly for evidence of substantial governance benefits in connection to arbitration is one that I coauthored with Chris Drahozal. ${ }^{20}$ Our study examines franchise contracts, many of which include arbitration provisions. We examined the factors that determine the presence of arbitration provisions in a franchise contract. Our results show that the traditional factors cited in the franchise literature as important aspects of governance have a substantial effect on the likelihood of an arbitration provision being present in the franchise contract.

To understand the results of my study with Chris Drahozal, it is helpful first to consider one of the fundamental results of the literature on the economics of franchise contracts. ${ }^{21}$ One key result is that the franchisee has an incentive under certain circumstances to "free ride" on the brand capital of the franchisor. For example, consider McDonald's. If an individual McDonald's franchisor cuts its costs and at the same time lowers the quality of its product, the franchisor will enjoy the full benefit of the cost reduction while externalizing the reputational harm to other business units in the chain. ${ }^{22}$ That is because many of the customers view each McDonald's outlet as interchangeable and associate any negative experience in quality with the whole enterprise. Given this, one of the major governance problems present in any franchise contract is discouraging franchisees from free riding on the franchisor's brand.

One empirical measure of the incentive to free ride is the percentage of business units owned by the franchisor. As that percentage increases, the incentive to free ride falls. That is because as more business units are owned by the franchisor itself, the less likely it is that

20 Christopher R. Drahozal \& Keith N. Hylton, The Economics of Litigation and Arbitration: An Application to Franchise Contracts, 32 J: Legal STud. 549 (2003).

21 See Paul H. Rubin, The Theory of the Firm and the Structure of the Franchise Contract, 21 J.L. \& ECON. 223 (1978).

22 For example, McDonald's has a rule governing the number of minutes that a cooked hamburger can sit waiting for a customer to purchase it before it must be thrown out. An individual franchisor could cut its costs by violating the rule. However, many customers, who are often travelers, will attribute the bad experience to the whole franchise. 
any individual business unit will think that it can externalize any reduction in quality to other units in the chain.

Chris Drahozal and I found that the percentage of companyowned units in a franchise is negatively associated with the probability of an arbitration clause being present in the franchise contract. ${ }^{23}$ If arbitration provides governance benefits, as we hypothesize, this result would make sense. For on the theory that arbitration provides substantial governance benefits, it should be more important to have an arbitration provision as the likelihood of a dispute over free riding increases. And our findings show just such a correlation. As the likelihood of a dispute over free riding increases (which happens as the percentage of company-owned units falls) the likelihood of an arbitration provision in the franchise contract also increases.

The finding of a statistically significant, negative correlation between the percentage of company-owned units in a franchise network and the probability of an arbitration clause appearing in the franchise contract suggests that arbitration enhanced governance benefits in the sample of franchise contracts that Chris Drahozal and I studied. The likely reason for this is that arbitration provides a forum in which industry experts can determine whether a franchisee's conduct should be considered a valid basis for termination of the franchise contract. The alternative forum for deciding this question, the courts, would ask a jury to answer this question. Given the large number of ways in which a franchisee could appear to be complying with the provisions of a franchise contract while at the same time violating contract norms, it is quite plausible that arbitration provides a more accurate forum for determining whether the franchisor had a valid basis for terminating a contract.

We also found evidence that arbitration provisions are designed to avoid over-deterrence from excessive litigation and to minimize enforcement costs. For example, we found that the likelihood of an arbitration provision jumps substantially if the parties have included a contract provision limiting punitive damage awards. ${ }^{24}$ That suggests that if the franchisors are concerned that terminated franchisees will go to court to seek large punitive damages, they are especially likely to try to avoid that outcome by seeking to channel their disputes into arbitration. In addition, we found that franchisors whose home offices were located in a litigious jurisdiction were more likely to seek arbitration than other franchisors. ${ }^{25}$

23 Drahozal \& Hylton, supra note 20, at $\mathbf{5 7 5}$.

24 Id. at $\mathbf{5 7 4 .}$

$25 I d$. 
The empirical evidence reviewed here suggests that governance benefits are an important reason that we see arbitration agreements. This has important implications for the public debate on arbitration.

First, the finding that governance benefits provide a major reason for arbitration agreements goes against the oft-repeated view that arbitration contracts operate in effect as waivers. In other words, the oftrepeated view is that potential plaintiffs sign away their legal rights when they enter into arbitration regimes. However, the Eisenberg and Hill, and Drahozal and Hylton studies suggest that arbitration contracts do not operate as waiver agreements. To the extent that they enhance governance benefits, they enhance at least some legal rights.

Second, the empirical results on arbitration and governance benefits suggest that the benefits of arbitration are more widespread than typically thought. If arbitration agreements involved nothing more than the waiver of rights, they would provide few if any social benefits because they would simply redistribute costs. In addition, if arbitration agreements simply reduced litigation costs, they would be beneficial, but in a limited sense connected to litigation. The finding that they enhance governance benefits suggests that they result in organizations working more effectively on a day-to-day basis. For example, if arbitration agreements enhance governance benefits in franchise networks, then they probably reduce the risk of free riding behavior within these networks. Reducing the frequency of free riding leads, in turn, to more reliable, effective franchises.

I do not wish to be understood as providing an unqualified defense of arbitration agreements. Of course it is possible for arbitration agreements to reduce the overall welfare of the contracting parties or of society in general. ${ }^{26}$ But that is also true of litigation-it may or may not enhance society's welfare. ${ }^{27}$ The theory of litigation and arbitration has reached the stage where it is beginning to suggest useful empirical tests of the social value of arbitration. The empirical evidence on arbitration agreements remains sparse, and much more work needs to be done in this area. I am hopeful that policy debates concerning arbitration will soon be informed by solid empirical research rather than speculation.

26 Hylton, supra note 1 , at 230.

27 Steven Shavell, The Social Versus the Private Incentive to Bring Suit in a Costly Legal System, 11 J. Legal STud. 333, 339 (1982) (using equations and numerical examples to describe the social and private costs of litigation). 